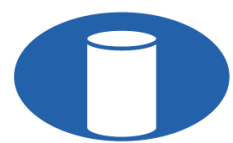

IBRACON

\title{
Effect of the water/binder ratio on the hydration process of Portland cement pastes with silica fume and metakaolin
}

\section{Efeito da relação água/aglomerante no processo de hidratação de pastas de cimento Portland com sílica ativa e metacaulim}

\author{
Mara Monaliza Linhares Pereira ${ }^{\mathrm{a}}$ (i) \\ Ana Luiza Rocha de Souza ${ }^{\mathrm{a}}$ (1) \\ Valdirene Maria Silva Capuzzo ${ }^{\mathrm{a}}$ \\ Rodrigo de Melo Lameiras ${ }^{\mathrm{a}}$ (i)
}

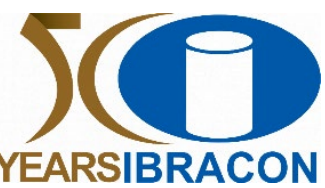

${ }^{a}$ Universidade de Brasília - UnB, Departamento de Engenharia Civil e Ambiental, Programa de Pós-graduação em Estruturas e Construção Civil, Brasília, DF, Brasil

Received 03 January 2021

Accepted 02 May 2021

\begin{abstract}
The microstructure of cement pastes is important to understand the effect of some parameters in the hydration process. In this context, this study had as objective to evaluate the effect of different water/binder $(\mathrm{w} / \mathrm{b})$ ratios in the hydration process of cementitious pastes produced with and without incorporation of silica fume and metakaolin. The pastes were obtained with water/binder ratios of $0.3,0.4 \mathrm{e} 0.5$, with replacement, by weight, of Portland cement for silica fume and metakaolin, in the contents of $10 \%$ and $20 \%$, respectively. It was performed the X-ray diffraction test of the pastes in the ages of $1,3,7$, and 28 days, to evaluate the hydration evolution of the cementitious materials. According to the results obtained, it was observed that the cementitious pastes presented similar mineralogical phases, except for the pastes containing metakaolin due to the formation of new aluminate phases. With the increase of the water/binder ratio, the pozzolanic reactions and hydration occurred in greater proportion, standing out the metakaolin with greater reactivity.
\end{abstract}

Keywords: cementitious pastes, water/binder, X-ray diffraction, silica fume, metakaolin.

Resumo: A microestrutura das pastas de cimento é importante para compreender o efeito de alguns parâmetros no processo de hidratação. Nesse contexto, este trabalho teve como objetivo avaliar o efeito de diferentes relações água/aglomerante (a/agl) no processo de hidratação de pastas cimentícias produzidas com e sem incorporação de sílica ativa e metacaulim. As pastas foram obtidas com relações água/aglomerante de $0,3,0,4$ e 0,5 , com substituição em massa do cimento Portland por sílica ativa e metacaulim, nos teores de $10 \%$ e $20 \%$, respectivamente. Foi realizado o ensaio de difração de raios-X das pastas nas idades de 1, 3, 7 e 28 dias, para avaliar a evolução da hidratação dos materiais cimentícios. De acordo com os resultados obtidos, observou-se que as pastas cimentícias apresentaram fases mineralógicas semelhantes, com exceção das pastas contendo metacaulim devido à formação de novas fases aluminato. Com o aumento da relação água/aglomerante, as reações pozolânicas e de hidratação ocorreram em maior proporção, se destacando o metacaulim com maior reatividade.

Palavras-chave: pastas cimentícias, água/aglomerante, difração de raios-X, sílica ativa, metacaulim.

How to cite: M. M. L. Pereira, A. L. R. Souza, V. M. S. Capuzzo, and R. M. Lameiras, "Effect of the water/binder ratio on the hydration process of Portland cement pastes with silica fume and metakaolin," Rev. IBRACON Estrut. Mater., vol. 15, no. 1, e15105, 2022,

https://doi.org/10.1590/S1983-41952022000100005

\section{INTRODUCTION}

Understanding the influence of each phase of cementitious pastes is important for the development of a transition zone more efficient, with greater hydration speed, and better performance of the mechanical properties and durability. The deformation

Corresponding author: Mara Monaliza Linhares Pereira. E-mail: maramonaliza19@gmail.com

Financial support: CAPES, CNPq, FAP-DF (Process: 0193.001700/2017).

Conflict of interest: Nothing to declare. 
capacity of concrete is connected to intrinsic characteristics of cement hydration products, aggregates, transition zone, and pores, besides other particular variables to process, such as hydration speed and climatic conditions [1]. The Portland cement, when hydrated, has as main phases the hydrated calcium silicate (C-S-H) and the calcium hydroxide $(\mathrm{CH})$, which are directly connected to the physical and mechanical properties of construction materials [1], [2]. Also, the water/cement (w/c) ratio is one of the parameters to control the micro and nanostructure of these phases [1].

Due to the environmental impact caused by the extraction of raw materials and $\mathrm{CO}_{2}$ emission in cement production has been sought a reduction of the consumption of this constituent of concrete, together with the need to increase the durability [3], [4]. In this context, it arises as an alternative the using supplementary cementitious materials (SCMs) in partial replacement to Portland cement [4]-[8]. Among these materials, metakaolin and silica fume, are the mineral additions most commonly used in the last years in the production of cementitious materials and have a high reactivity due to their pozzolanic activity [9]-[14]. These SCMs generally provide more silica and alumina to the cementitious matrix, thus, the final composition of the C-S-H and the quantity, secondary phases, are affected [2].

Numerous researchers investigated the effects of these SCMs in the performance of cementitious materials such as cement pastes, mortars, and concretes [2]-[4], [7], [9], [11]-[15], [16]-[19]. The mineral additions cause influence on the hydration kinetics of cement Portland, and through chemical activity, forms secondary hydrated products. As a consequence of this behavior, the microstructure of the cementitious matrix suffers a change [20]. According to these researches, the SCMs improve the properties of mechanical strength and increase the durability of the structures due to their pozzolanic reactions and the high fineness that contributes to the refinement of pores, decreasing of this way the final porosity and improving the cohesion of the mixture in the fresh state [9], [18], [21].

The hydration reactions of the cement and the release of heat are directly related to several parameters: the composition of the binder, type and content of the supplementary cementitious materials used in replacement to clinker, chemical admixture added, water/cement ratio and curing temperature. Independent of these parameters, a series of simultaneous and successive reactions are responsible for the gain of consistency or loss of workability, which generates the consolidation of suspensions and consequent resistance gain [22]. Furthermore, understand the microstructure of cement pastes is important to understand the effect of various conditions on the hydration process [23].

Although the effect of the water/binder $(w / b)$ ratio and the effect of supplementary cementitious materials (SCMs) have already been objective of several studies [9]-[11], [14], [19], most of these studies are limited to evaluate the effects on physical and mechanical properties in different cementitious matrices. Also, the studies that evaluate the joined effect of the w/b ratio and SCMs in the microstructure of Portland cement pastes are still limited. Therefore, there is a need for studies to better understand the combined effect of the water/binder factor and additions of silica fume and metakaolin in the hydration process through the development of the microstructure of cementitious pastes.

Taking into consideration the importance of the presence of water in the hydration process and the lack of more comprehensive studies to understand the effect of the synergy between pozzolanic additions and the water/binder ratio, the present article aimed to evaluate the joint effect of different $\mathrm{w} / \mathrm{b}$ ratios and supplementary cementitious materials in the hydration process of cementitious pastes through the microstructural analysis of $\mathrm{X}$ ray diffraction.

\section{MATERIALS AND EXPERIMENTAL PROGRAM}

\subsection{Materials}

\subsubsection{Portland cement}

The cement used was of type V (CP V), characterized by conferring a high resistance in the first moments of concrete curing, according to NBR 16697 [24]. The choice of this binder happened of using cement with lower content of pozzolanic additions in its composition when in comparison to other types of cement available on the market, seeking this way to avoid combined effects and evaluate the influence of metakaolin and silica fume in cementitious pastes. Table 1 presents the data obtained, as well as the methods used, in the physical and chemical characterization of this material. The chemical characterization was obtained through the X-ray fluorescence spectrometry (XRF) test, performed on an EDX 720 Shimadzu device. Before performing the XRF test, it was performed the loss on ignition test with the base on the guidelines of ABNT NM 18 [25]. 
Table 1. Properties and characteristics of the Portland cement (CP V).

\begin{tabular}{|c|c|c|c|c|}
\hline \multicolumn{2}{|c|}{ Properties and characteristics } & Results & Limits $^{(a)}$ & Test method \\
\hline \multirow{2}{*}{ Setting time } & Initial (min) & 120 & $\geq 60$ & \multirow{2}{*}{ ABNT NBR 16607 [26] } \\
\hline & Final (min) & 175 & $\leq 600$ & \\
\hline \multicolumn{2}{|c|}{ Water content of normal consistency paste $(\%)$} & 35.50 & - & ABNT NBR 16606 [27] \\
\hline \multicolumn{2}{|c|}{ Fineness index on sieve \#200 (\%) } & 0.90 & $\leq 6.0$ & ABNT NBR 11579 [28] \\
\hline \multicolumn{2}{|c|}{ Specific mass $\left(\mathrm{g} / \mathrm{cm}^{3}\right)$} & 3.00 & - & ABNT NBR 16605 [29] \\
\hline \multirow{3}{*}{ Compressive strength (MPa) } & 1 day & 25.4 & $\geq 14.0$ & \multirow{3}{*}{ ABNT NBR 7215 [30] } \\
\hline & 3 days & 36.1 & $\geq 24.0$ & \\
\hline & 7 days & 42.7 & $\geq 34.0$ & \\
\hline \multirow{11}{*}{ Chemical composition, in oxides $(\%)$} & $\mathrm{CaO}$ & 63.61 & - & - \\
\hline & $\mathrm{SiO}_{2}$ & 19.91 & - & - \\
\hline & $\mathrm{Al}_{2} \mathrm{O}_{3}$ & 4.20 & - & - \\
\hline & $\mathrm{Fe}_{2} \mathrm{O}_{3}$ & 2.20 & - & - \\
\hline & $\mathrm{MgO}$ & 1.78 & $\leq 6.5$ & - \\
\hline & $\mathrm{Na}_{2} \mathrm{O}$ & 0.38 & - & - \\
\hline & $\mathrm{K}_{2} \mathrm{O}$ & 0.36 & - & - \\
\hline & $\mathrm{TiO}_{2}$ & 0.23 & - & - \\
\hline & $\mathrm{P}_{2} \mathrm{O}_{5}$ & 0.17 & - & - \\
\hline & $\mathrm{MnO}$ & 0.07 & - & - \\
\hline & $\mathrm{LOI}^{(\mathrm{b})}$ & 3.36 & $\leq 6.5$ & ABNT NM 18 [25] \\
\hline
\end{tabular}

(a) Limits established by the ABNT NBR 16697 [24]. (b) Loss on ignition (LOI)

According to Table 1, the chemical composition indicates a predominance of calcium oxide and silicon dioxide, as expected for the type of cement used and also observed in the studies of [3], [11], [31].

The X-ray diffraction test of Portland cement was also performed to identify the compounds of crystalline phases. For this test, it was used the RIGAKU X-ray diffractometer model ULTIMA IV, operating with a tungsten filament as a cathode and a copper $\mathrm{X}$-ray tube $(\mathrm{CuKa}=1.54056 \mathrm{~A})$, under $35 \mathrm{kV}$ power and $15 \mathrm{~mA}$ current, in the range of $2 \theta$ equal to $2^{\circ}$ until $60^{\circ}$. The scanning velocity was $5^{\circ} / \mathrm{min}$ and steps of $0.05^{\circ}$. As presented in Figure 1 , observing the diffractogram were identified the compounds alite, gypsum, belite, ferrite, and calcite, which are compounds formed from the materials used in the production of cement.

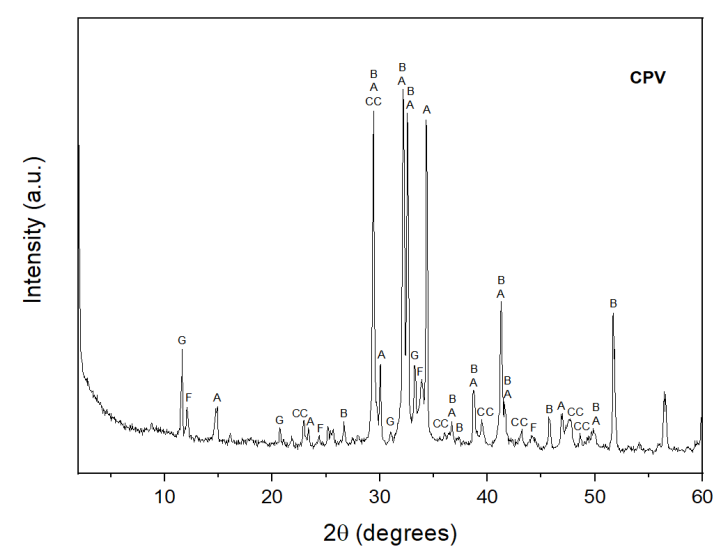

Figure 1. X-ray diffractogram of the Portland cement (CP V). G-gypsum, F-ferrite, A-alite, CC-calcite, B-belite.

\subsubsection{Metakaolin}

It was used a metakaolin of high reactivity as partial substitution, by weight, of $\mathrm{CP} V$, in the cementitious pastes. This material is characterized by containing a high content in alumina and being quite fine, as can be verified in Table 2 , where are the results of the analysis of some physical properties and the chemical characterization obtained through the X-ray fluorescence spectrometry (XRF) test. 
Table 2. Physical and chemical properties of the metakaolin.

\begin{tabular}{|c|c|c|c|}
\hline \multicolumn{2}{|c|}{ Properties and characteristics } & Results & Test method \\
\hline \multicolumn{2}{|c|}{ Specific mass $\left(\mathrm{g} / \mathrm{cm}^{3}\right)$} & 2.60 & ABNT NBR 16605 [29] \\
\hline \multicolumn{2}{|c|}{ Diameter below which it finds $10 \%$ of the particles $-\mathrm{D} 10(\mu \mathrm{m})$} & 1.77 & \multirow{3}{*}{ Laser granulometry } \\
\hline \multicolumn{2}{|c|}{ Mean diameter $(\mu \mathrm{m})$} & 18.27 & \\
\hline Diameter below which it finds 90 & $-\mathrm{D} 90(\mu \mathrm{m})$ & 39.36 & \\
\hline \multirow{11}{*}{ Chemical composition, in oxides $(\%)$} & $\mathrm{SiO}_{2}$ & 50.54 & - \\
\hline & $\mathrm{CaO}$ & 0.00 & - \\
\hline & $\mathrm{Al}_{2} \mathrm{O}_{3}$ & 42.28 & - \\
\hline & $\mathrm{Fe}_{2} \mathrm{O}_{3}$ & 3.23 & - \\
\hline & $\mathrm{TiO}_{2}$ & 1.63 & - \\
\hline & $\mathrm{K}_{2} \mathrm{O}$ & 1.07 & - \\
\hline & $\mathrm{MgO}$ & 1.02 & - \\
\hline & $\mathrm{SO}_{3}$ & 0.09 & - \\
\hline & $\mathrm{ZrO}_{2}$ & 0.03 & - \\
\hline & $\mathrm{Cr}_{2} \mathrm{O}_{5}$ & 0.03 & - \\
\hline & $\mathrm{SrO}$ & 0.01 & - \\
\hline
\end{tabular}

From Table 2, it is possible to observe some main chemical compounds for its mineral formation. Metakaolin is obtained from the calcination of kaolinitic clays, so it is basically composed of silica $\left(\mathrm{SiO}_{2}\right)$ and alumina $\left(\mathrm{Al}_{2} \mathrm{O}_{3}\right)$ in the amorphous phase, as confirmed with the obtained chemical composition.

The granulometric curve of the metakaolin was obtained through the laser granulometry test, and it is presented in Figure 2. This test was performed using a particle size analyzer model CILAS 1180 in liquid mode with an analysis range from 0.04 to $2500.00 \mu \mathrm{m}$.

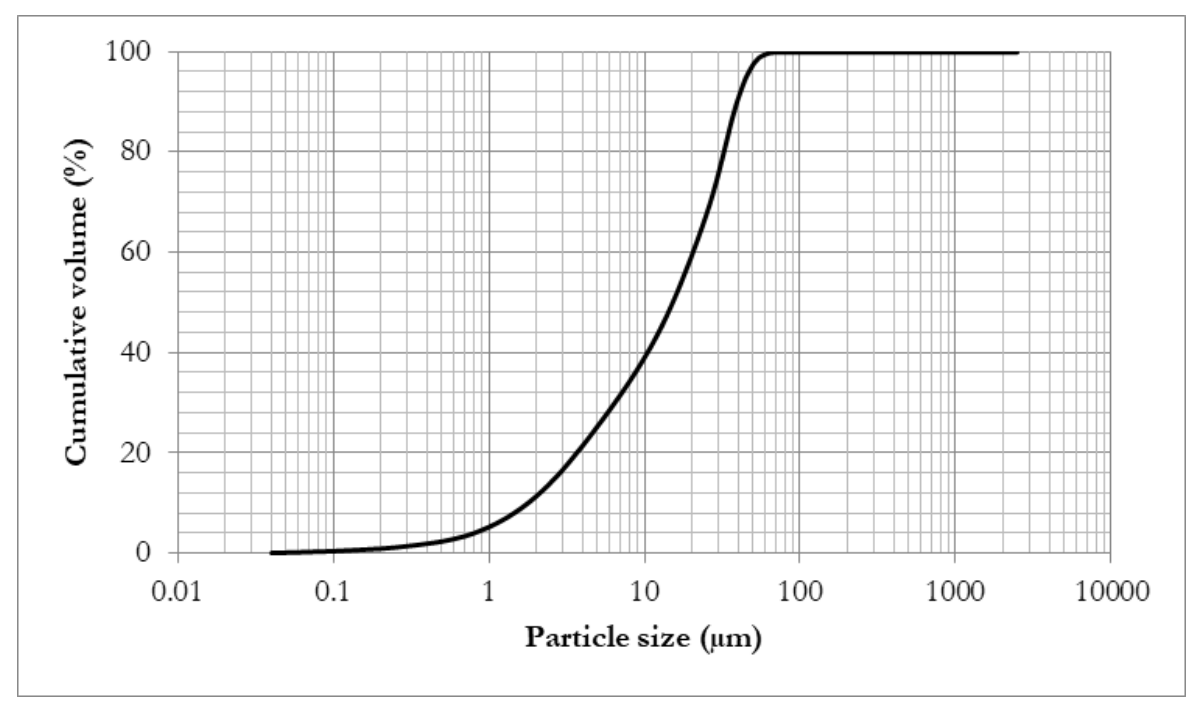

Figure 2. Granulometric curve of the metakaolin.

Also, it was performed the X-ray diffraction test for metakaolin through the same X-ray diffractometer model used in the characterization of $\mathrm{CP} \mathrm{V}$ cement, operating only with a different $2 \theta$ interval, which was equal to $2^{\circ}$ until $80^{\circ}$ for the metakaolin. It is important to reinforce that despite the change of the interval for this material, it was followed the same standardization for other parameters, mainly in the placing of the material in the sample holder, to avoid any interference in the peaks due to the targeting of the crystalline plane during the execution of the test. In the diffractogram presented in Figure 3, it can be identified peaks of quartz, kaolinite, and muscovite, beyond the presence of an amorphous halo that characterizes the reactivity of this material. 


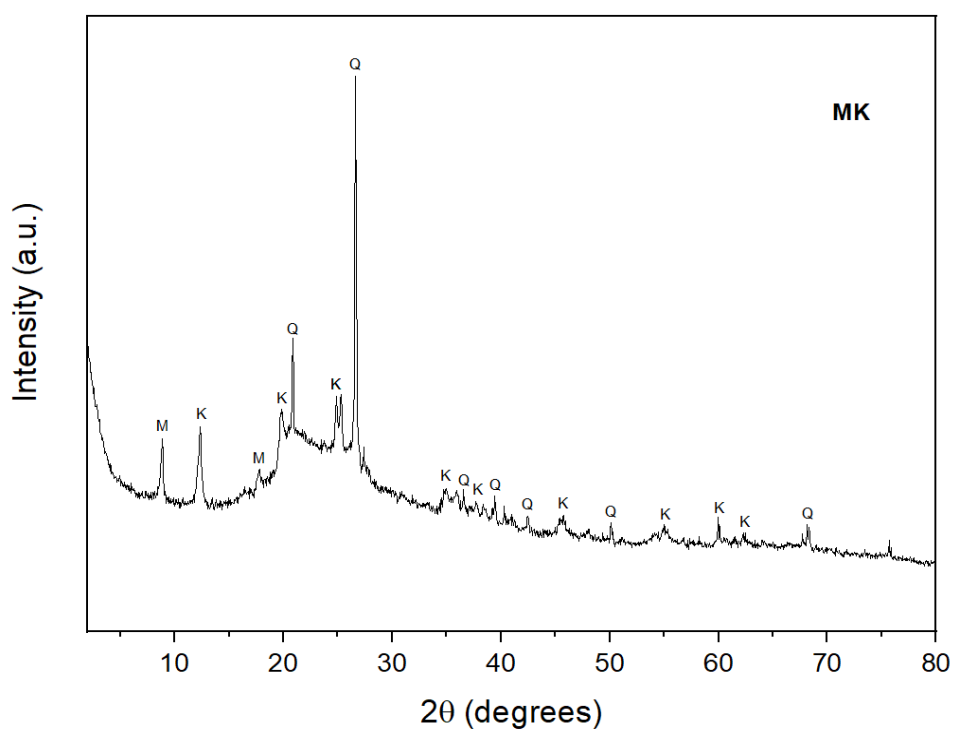

Figure 3. X-ray diffractogram of the metakaolin. M-muscovite, K-kaolinite, Q-quartz.

\subsubsection{Silica fume}

It was also used, in binary mixtures, a densified silica fume as partial substitution, by weight, of $\mathrm{CP} \mathrm{V}$, in cementitious pastes. This material is a pozzolanic mineral addition that presents fine particles and has a high specific area, as can be verified in Table 3, which presents the results of physical and chemical characterization of the silica fume. In the same way that for the previous materials, the chemical characterization was obtained through the X-ray fluorescence spectrometry (XRF) test, and before performing the test, it was performed the loss on ignition test with a base on the guidelines of ABNT NM 18 [25].

Table 3. Physical and chemical properties of the silica fume.

\begin{tabular}{|c|c|c|c|c|}
\hline \multicolumn{2}{|l|}{ Properties and characteristics } & Results & Limits $^{(a)}$ & Test method \\
\hline \multicolumn{2}{|l|}{ Apparent density $\left(\mathrm{kg} / \mathrm{m}^{3}\right)$} & 595.07 & - & ABNT NM $45[32]$ \\
\hline \multicolumn{2}{|l|}{ Fineness in the sieve $45 \mu \mathrm{m}(\%)$} & 9.10 & 10.0 & ABNT NBR 13956-4 [33] \\
\hline \multicolumn{2}{|c|}{ Specific mass $\left(\mathrm{g} / \mathrm{cm}^{3}\right)$} & 2.16 & - & ABNT NBR 16605 [29] \\
\hline \multicolumn{2}{|c|}{ Specific surface area values (B.E.T.) $\left(\mathrm{m}^{2} / \mathrm{g}\right)$} & 19.72 & $15 \leq$ B.E.T. $\leq 30$ & ASTM C1069 [34] \\
\hline \multicolumn{2}{|c|}{$\begin{array}{l}\text { Diameter below which it finds } 10 \% \text { of the particles }-\mathrm{D} 10 \\
\qquad(\mu \mathrm{m})\end{array}$} & 5.19 & (1) & \multirow{3}{*}{ Laser granulometry } \\
\hline \multicolumn{2}{|c|}{ Mean diameter $(\mu \mathrm{m})$} & 31.55 & - & \\
\hline \multicolumn{2}{|c|}{$\begin{array}{l}\text { Diameter below which it finds } 90 \% \text { of the particles - D90 } \\
\qquad(\mu \mathrm{m})\end{array}$} & 58.75 & - & \\
\hline \multirow{11}{*}{ Chemical composition, in oxides $(\%)$} & $\mathrm{SiO}_{2}$ & 94.33 & $\geq 85$ & - \\
\hline & $\mathrm{K}_{2} \mathrm{O}$ & 1.04 & - & - \\
\hline & $\mathrm{CaO}$ & 0.78 & - & - \\
\hline & $\mathrm{MgO}$ & 0.49 & - & - \\
\hline & $\mathrm{Na}_{2} \mathrm{O}$ & 0.39 & - & - \\
\hline & $\mathrm{Fe}_{2} \mathrm{O}_{3}$ & 0.19 & - & - \\
\hline & $\mathrm{P}_{2} \mathrm{O}_{5}$ & 0.14 & - & - \\
\hline & $\mathrm{MnO}$ & 0.06 & - & - \\
\hline & $\mathrm{TiO}_{2}$ & 0.02 & - & - \\
\hline & $\mathrm{Al}_{2} \mathrm{O}_{3}$ & $<0.01$ & - & - \\
\hline & $\mathrm{LOI}^{(\mathrm{b})}$ & 2.28 & $\leq 6.0$ & ABNT NM 18 [25] \\
\hline
\end{tabular}

(a) Limits established by the ABNT NBR 13956-1 [35]. (b) Loss on ignition (LOI) 
From Table 3, it is possible to observe that the main chemical compound of the silica fume was silicon dioxide, which was already expected for this type of material, due to its obtaining to be from the production of metallic silicon or iron-silicon alloys.

The granulometric curve of the silica fume was obtained through the laser granulometry test, and it is presented in Figure 4. This test was performed using a particle size analyzer model CILAS 1180, which provides a measuring range of particle size between 0.04 to $2500.00 \mu \mathrm{m}$. For this test, the silica fume was placed under the effect of ultrasonic pulses for 60 seconds to deagglomerate the particles, which were placed in the equipment. However, even after 60 seconds on ultrasound, as it was a densified silica, it was still observed a large number of particles with large diameters, as observed in the results obtained from the laser granulometry test, presented in Table 3.

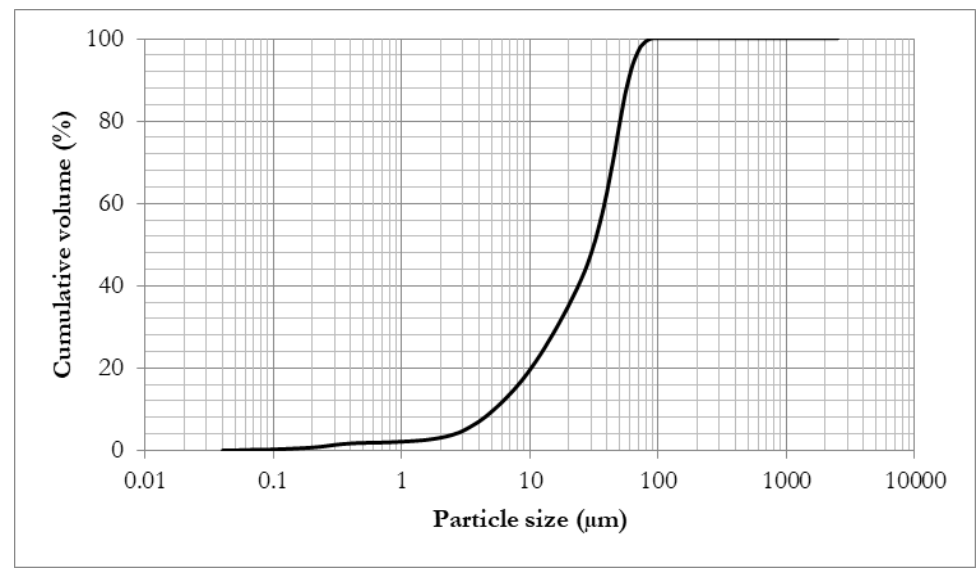

Figure 4. Granulometric curve of the silica fume.

For the mineralogical characterization of the silica fume, it was performed the X-ray diffraction test, through the same equipment and parameters used in the test for characterization of the cement $\mathrm{CP} V$, in which the silica fume presented a high degree of amorphism. In the diffractogram presented in Figure 5, it can be identified as characteristic peaks, the potassium chloride and silicon carbide.

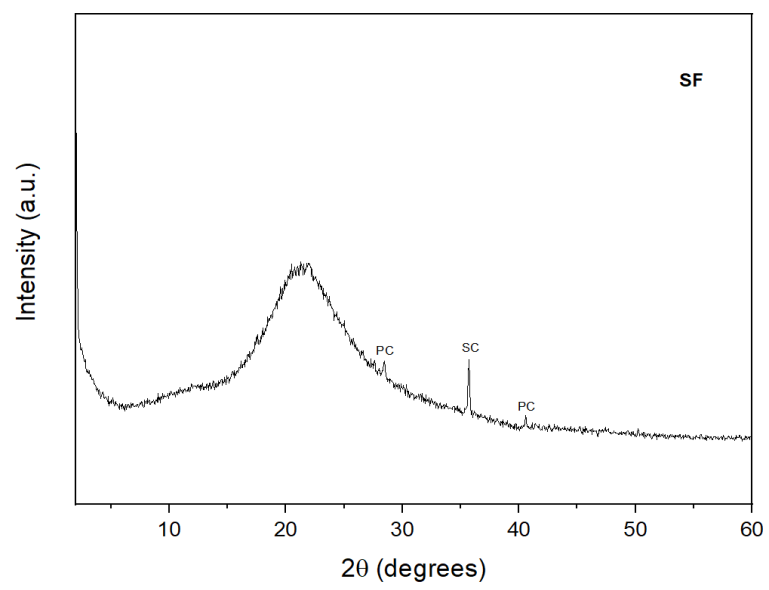

Figure 5. X-ray diffractogram of the silica fume. PC-potassium chloride, SC-silicon carbide.

\subsubsection{Potable water}

For the production of cement pastes, it was used the water provided by the water supply company of the Brasilia region, free of visible impurities and following of the ABNT NBR 15900-1 [36]. 


\subsection{Composition and preparation of cementitious pastes}

To evaluate the combined effect of the water/binder ratio and supplementary cementitious materials in the hydration process of cementitious matrices, it was studied a total of 9 Portland cement pastes varying the supplementary cementitious material, substituted concerning the cement mass, and the $\mathrm{w} / \mathrm{b}$ ratio. A nomenclature was defined for each sample to be studied to distinguish with more facility, starting by the cement paste without SCMs (reference paste), followed by two more percentages of substitution of the metakaolin or silica fume by the cement mass ( $20 \%$ and $10 \%$, respectively), and three distinct water/binder ratios $(0.30,0.40$ and 0.50$)$. It was opted to work with mass substitutions thinking about getting a reduction of the consumption of Portland cement in the cementitious pastes and as a measure of reducing retraction problems for Portland cement pastes with low water/binder ratio. Also, the content of the SCMs was chosen thought of other studies that observed optimum contents in a range of $8 \%$ to $20 \%$ for metakaolin [3], and 5 to $15 \%$ for silica fume [2]. Table 4 presents the adopted nomenclatures, being that REF meaning reference, MK is metakaolin, SF is silica fume, and the last number is the water/binder ratio.

Table 4. Nomenclature and composition of the traces.

\begin{tabular}{|c|c|c|}
\hline $\mathbf{w} / \mathbf{b}$ ratio & Abbreviation & Cementitious pastes \\
\hline \multirow{3}{*}{0.30} & REF03 & $100 \% \mathrm{CP} \mathrm{V}$ \\
\hline & MK03 & $80 \% \mathrm{CP} V+20 \%$ metakaolin \\
\hline & SF03 & $90 \% \mathrm{CP} \mathrm{V}+10 \%$ silica fume \\
\hline \multirow{3}{*}{0.40} & REF04 & $100 \% \mathrm{CP} \mathrm{V}$ \\
\hline & MK04 & $80 \% \mathrm{CP} \mathrm{V}+20 \%$ metakaolin \\
\hline & SF04 & $90 \% \mathrm{CP} V+10 \%$ silica fume \\
\hline \multirow{3}{*}{0.50} & REF05 & $100 \% \mathrm{CP} \mathrm{V}$ \\
\hline & MK05 & $80 \% \mathrm{CP} \mathrm{V}+20 \%$ metakaolin \\
\hline & SF05 & $90 \%$ PC V $+10 \%$ silica fume \\
\hline
\end{tabular}

The pastes were produced following the recommendations of ABNT NBR 16606 [27], using a mechanical mixer and the mixing sequence was performed in the following order: firstly, it was placed in the vat all the quantity of water, it was added the cement, followed of mineral addition when necessary, and it was performed the mixture during 30 seconds, at low speed. Then, it was turned off the mixer for 60 seconds to perform the scraping of the inner walls of the vat, causing all the paste adhered to them to stay at the bottom of the vat. Finally, the mixer was turned on again at high speed for 60 seconds.

After all the mixing and molding process, the cementitious paste samples were kept in a humid chamber for 24 hours, in which at that moment it became all necessary care with the samples so that no changes would occur in the w/b ratio. After the 24 hours period, the samples were placed in submerged curing of water saturated with lime, until the age of performing of the X-ray diffraction test, 1, 3, 7, and 28 days.

\subsection{X-ray diffraction (XRD)}

The X-ray diffraction test (XRD) was performed on the pastes at 1,3, 7, and 28 days of hydration, to identify the crystalline phases of the studied cementitious pastes. Upon completing the ages need for the performing of the test, the samples were broken and it was stopped the hydration of these pastes with the fragments of the internal part of the specimens, using the stoppage procedure described by Scrivener et al. [37]. The procedure consisted of the immersion of the fragments in isopropanol for 6 hours and drying in an oven at $\pm 40^{\circ} \mathrm{C}$ for 24 hours. Then, the samples were stored in a desiccator containing silica gel and soda-lime until the day of the performance of the test.

For the performance of the X-ray diffraction test, the granulometry of the samples was reduced, until all the material passed through the sieve $200(0.075 \mu \mathrm{m})$. Then, the sample in powder was spread over the excavated glass slide, making movements not oriented, avoiding the overlapping of the crystals and the favoring of some compounds in detriment to others, during the X-ray scanning. For all samples, it was followed the same procedure for placing the material in the sample holder, to avoid any interference in the crystalline peaks.

It was performed the tests on the same X-ray diffractometer model used in the characterization of the SCMs, operating with a tungsten filament as a cathode and a copper X-ray tube $(\mathrm{CuKa}=1.54056 \mathrm{~A})$, under $35 \mathrm{kV}$ power and $15 \mathrm{~mA}$ current, in the range of $2 \theta$ equal to $2^{\circ}$ until $60^{\circ}$. The scanning velocity was $5^{\circ} / \mathrm{min}$ and steps of $0.05^{\circ}$. The identification of the crystalline phases was performed with the aid of the JADE 3.0 software. 


\section{RESULTS AND DISCUSSIONS}

\subsection{Evaluation of the effect of water/binder ration on pastes by age in the hydration process}

The diffractograms of the cement pastes without supplementary cementitious materials (SCMs), reference pastes, are presented in Figure 6 after 1 day (A), 3 days (B), 7 days (C), and 28 days (D) of hydration for the water/binder ratios of $0.3,0.4$ and 0.5 .

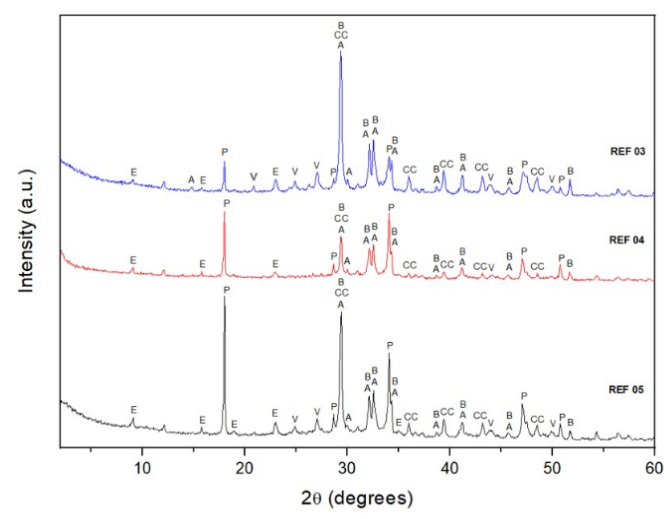

(A)

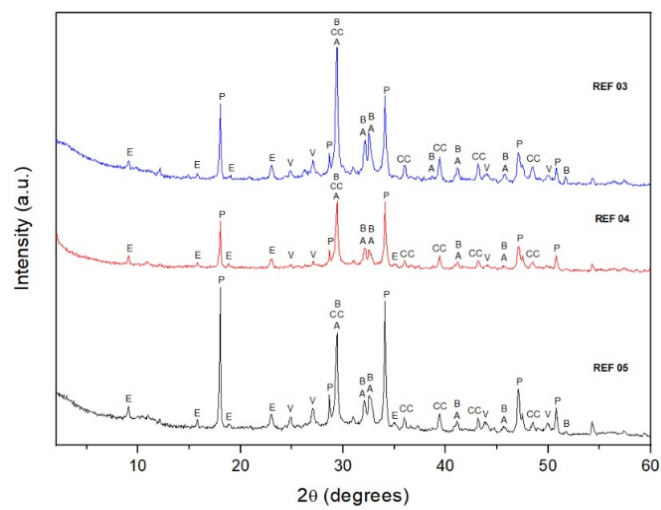

(C)

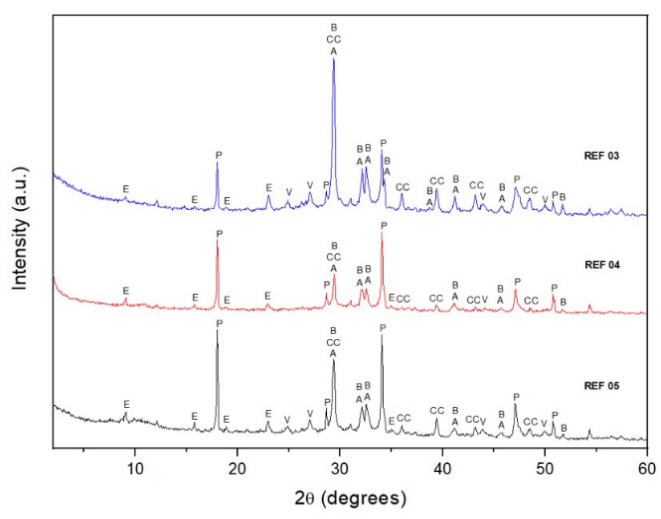

(B)

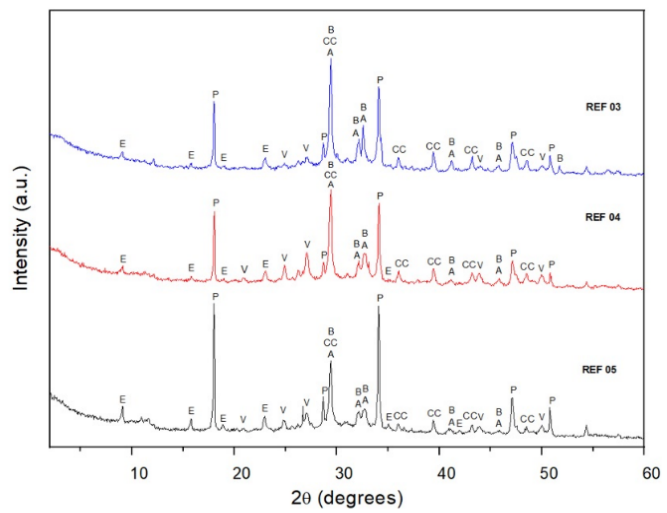

(D)

Figure 6. Diffractograms of the cement pastes without supplementary cementitious materials (SCMs), with 1 day (A), 3 days (B), 7 days (C), and 28 days (D) of hydration. E- ettringite, P-portlandite, V-vaterite, A-alite, CC-calcite, B-belite.

During the hydration process, it was observed the hydration products of the aluminate and silicate phases which are: ettringite (E) and calcium hydroxide or portlandite $(\mathrm{P})$, respectively, beyond some compounds present in the clinker that are the phases alite (A) and belite (B), and the products of calcium carbonate, calcite (CC) and vaterite (V).

With the advancement of hydration, it was possible to observe in all the reference pastes studied the increment of the portlandite peaks that are generated by the reactions of the silicate phases (alite and belite) with water, a behavior that is proven when observing the decrease of the peaks of alite and belite, that even decreasing still continue present until at 28 days. Another product that also presented a slight increment in its peaks and until the emergence of others was ettringite, which is the first product of hydration of the aluminate phases present in the Portland cement clinker. The presence of the calcium carbonate products in the pastes can be attributed to the chemical composition of Portland cement, which according to NBR 16697 [24] is allowed to have up to $10 \%$ of carbonate material. The presence of the carbonate material was confirmed through the mineralogical characterization of Portland cement, presented in Figure 1.

During the hydration of the cement, another main phase formed from the reactions of alite and belite is the hydrated calcium silicate (C-S-H) which does not have crystalline peaks, presenting this way an amorphous structure, which when present in the evolution of the cement hydration has its identification through the formation of amorphous halo in the X-ray diffractogram. The presence of C-S-H can also be identified using the X-ray diffraction technique together 
with the Rietveld method, for the performing of a quantitative analysis of the hydration products present in the studied material. Since quantification is not the objective of the study, in the qualitative analysis performed for the studied cementitious pastes, from the diffractograms in Figure 6, it was possible to identify the presence of C-S-H through the amorphous halo at 28 days of hydration, being more intense for the water/binder ratio of 0.5 .

It was also possible to observe, through the diffractograms, the importance of water in the hydration reactions, because at all ages with the increase of the water/binder ratio, it was noted an increment in the intensity of the peaks of portlandite and a reduction in the intensity of the alite and belite phases, being that in the cementitious pastes with a water/binder ratio of 0.5 , it was achieved the highest intensities for the products of portlandite. This situation can be confirmed through Neville and Brooks [38], who observed an interesting aspect when citing that there is a minimum water/cement ratio necessary for complete hydration, approximately 0.36 in mass, this is, for values below 0.36 , there is not enough space for the accommodation of all hydration products. This is due to the hydration can only occur when the capillary pores contain enough water to ensure a relative humidity internal high and not just the amount of water needed for the chemical reactions. Thus, through the qualitative analysis, it was confirmed that for very low water/binder values, there are less intense peaks of portlandite due to not having enough water for occurring total hydration, while for high values of $\mathrm{w} / \mathrm{b}$ there is a high intensity of portlandite peaks.

Figure 7 are presented the diffractograms of cement pastes containing $10 \%$ of mass substitution of silica fume after 1 day (A), 3 days (B), 7 days (C), and 28 days (D) of hydration for the three different water/binder ratios.

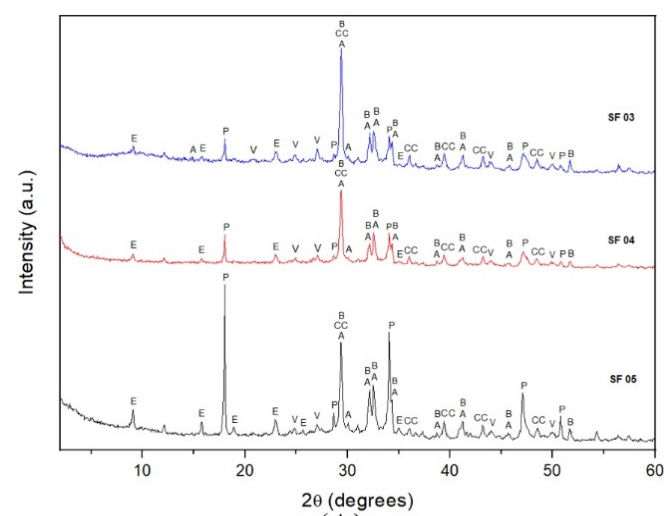

(A)

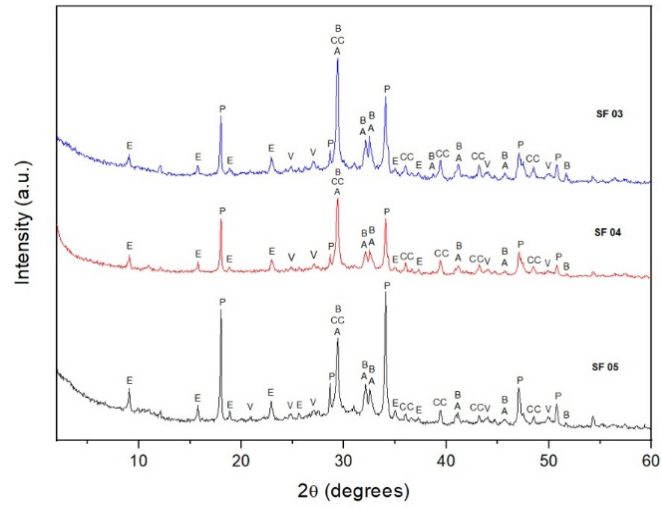

(C)

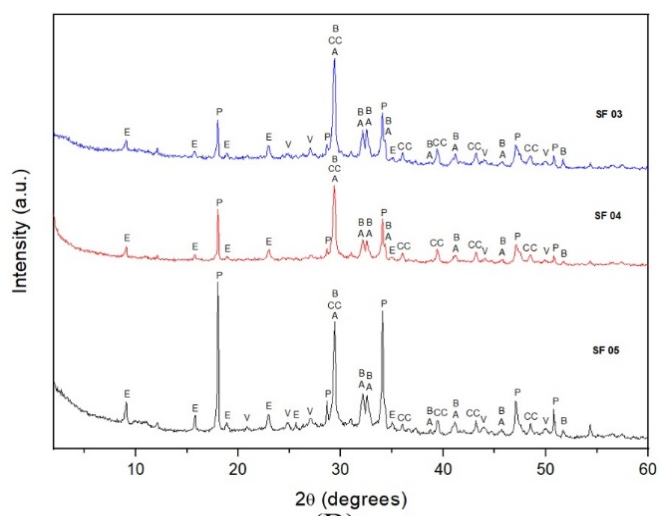

(B)

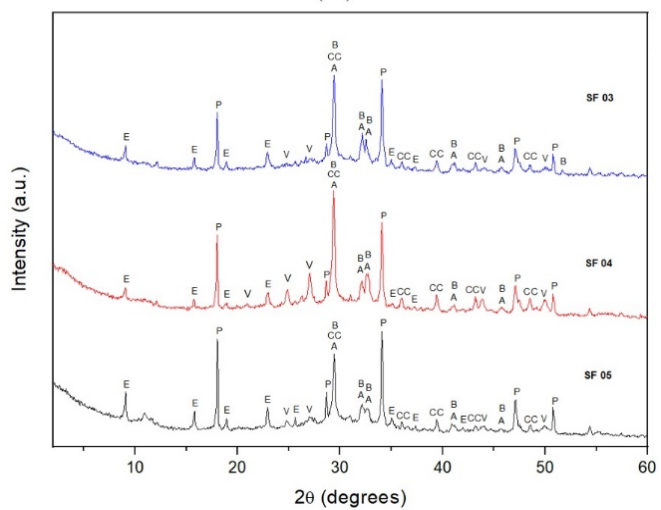

(D)

Figure 7. Diffractograms of the cementitious pastes with the replacement of Portland cement by $10 \%$ of silica fume, with 1 day (A), 3 days (B), 7 days (C), and 28 days (D) of hydration. E-ettringite, P-portlandite, V-vaterite, A-alite, CC-calcite, B-belite.

As observed through the qualitative analysis of the diffractograms in Figure 7, during the hydration process over the ages of pastes containing $10 \%$ of silica fume also presented the aluminates and silicates phases, represented by ettringite (E) and portlandite (P), the alite (A) and belite (B) phases, and the calcium carbonate products that are calcite (CC) and vaterite (V). With the advancement of the hydration, during the studied ages, it was observed the increase of the portlandite peaks, which appear from the reactions of the alite and belite phases, these reactions are proven through 
the reduction of the anhydrous cement peaks, which remain present until at 28 days. The ettringite peaks also presented slight increments in their intensities, due to the synergy between the materials. Also, the presence of calcite and vaterite, as previously mentioned, it is due to the type of cement CPV used, which presents until $10 \%$ of the limestone filler in its composition.

For cementitious pastes containing silica fume was also confirmed the importance of the water in the hydration process, because with the increase of the water/binder ratio was observed a behavioral trend similar to reference cementitious pastes. For a lower $w / b$ ratio, there is less intensity of the portlandite peaks, observing yet that in the initial ages this difference is greater, but it is due to the insufficient time for hydration reactions to happen completely.

Even working with $10 \%$ of silica fume, which is a reactive pozzolanic material, having a higher $\mathrm{w} / \mathrm{b}$ ratio, it was noted in the diffractograms a greater intensity of portlandite due to the greater amount of water in the mixture. However, it was noted consumption of portlandite and formation of C-S-H, for the age of 28 days, due to the effect of the pozzolanic reaction generated by silica fume, viewed through the identification of the presence of amorphous halo. Besides, as for a w/b ratio of 0.5 has a greater amount of portlandite available in the cementitious matrix to react with the silica fume, is observed an amorphous halo from the 3 days of hydration, presenting at 28 days an amorphous halo more intense.

Through the qualitative analysis of the diffractograms of cementitious pastes containing $10 \%$ of silica fume, it was observed that the water/binder ratios of 0.3 and 0.4 did not present any difference of behavior during the hydration process. While that to the $\mathrm{w} / \mathrm{b}$ ratio of 0.5 there is a greater amorphous halo, due to the consumption of portlandite generated by the pozzolanic addition, besides a greater intensity in the ettringite peaks, which is a hydration product that due to its microstructural morphology it is more susceptible to rupture.

The diffractograms of the cement pastes containing $20 \%$ of mass substitution of Portland cement by metakaolin are presented in Figure 8 after 1 day (A), 3 days (B), 7 days (C), and 28 days (D) of hydration for the three different water/binder ratios.

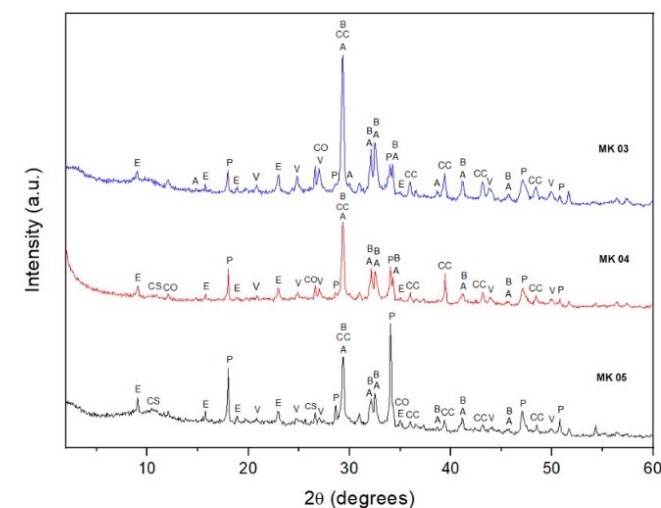

(A)

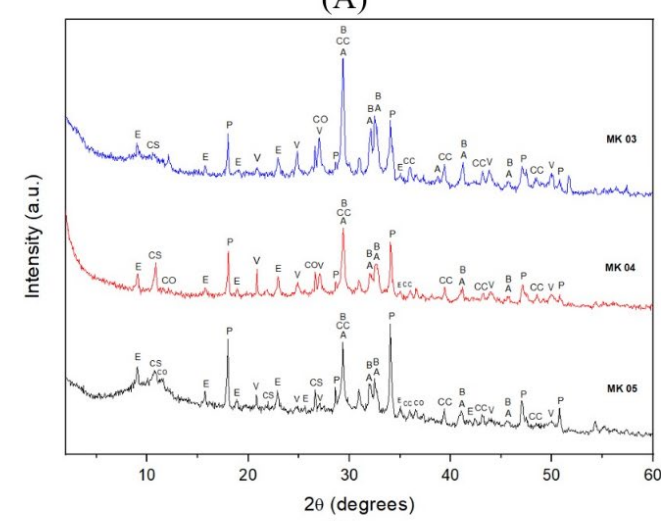

(C)

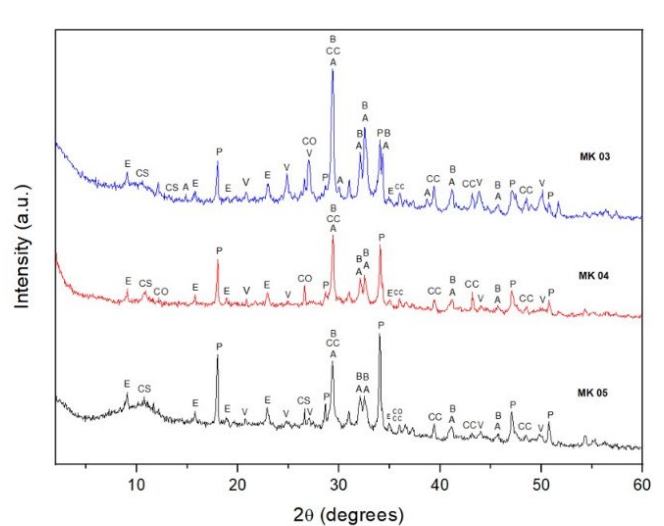

(B)

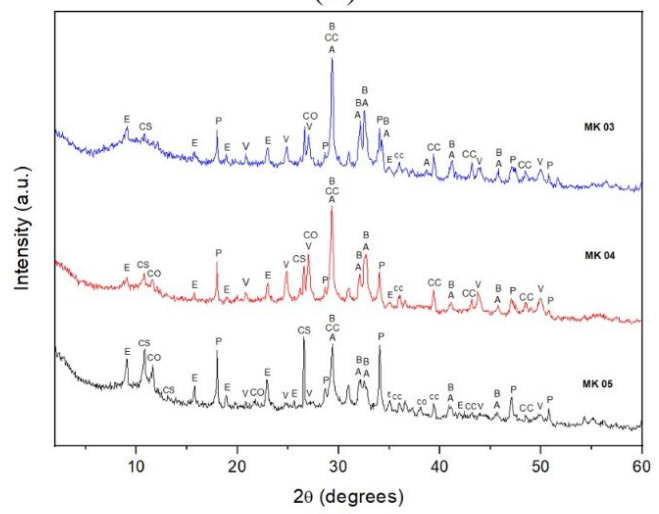

(D)

Figure 8. Diffractograms of the cementitious pastes with the replacement of Portland cement by $20 \%$ of metakaolin, with 1 day (A), 3 days (B), 7 days (C), and 28 days (D) of hydration. E- Ettringite, P-portlandite, V-vaterite, A-alite, CC-calcite, B-belite, CShydrated calcium aluminum silicate, CO-hydrated calcium aluminum oxide. 
Through the qualitative analysis of the diffractograms in Figure 8, it can be seen that during the hydration process, over the ages, the pastes containing $20 \%$ of metakaolin presented the aluminate and silicate phases which are: ettringite (E) and portlandite (P), the alite (A) and belite (B) phases, beyond of the calcite (CC) and vaterite (V).

It was identified yet two new hydration products named in this study by hydrated calcium aluminum silicate (CS) and hydrated calcium aluminum oxide (CO). These products were formed from the pozzolanic reaction of metakaolin, which happens through the interaction between metakaolinite and calcium hydroxide. The formation of the CS and CO phases in the pastes containing metakaolin is also responsible for the formation of the hydrated calcium carboaluminates, known as hemicarboaluminate (hc) and monocarboaluminate $(\mathrm{mc})$, when in the presence of limestone filler. Also, these carboaluminates (hc and $\mathrm{mc}$ ) were identified in the study by Antoni [6] when utilizing cementitious pastes substituting Portland cement with $30 \%$ of metakaolin and $15 \%$ of limestone filler.

With the advance of the hydration, during the studied ages, it was observed that until at 7 days it was possible to view an increment in the intensity of the portlandite peaks, being that at 28 days these peaks have already suffered a decrease of the intensity, in consequence of the pozzolanic reaction, which formed many more CS and CO products at 28 days than in the first 7 days of hydration. The increase of the portlandite crystals in the cementitious matrix is associated with the hydration reactions of the alite and belite phases, confirmed through the decrease of the anhydrous cement peaks present in the diffractograms analyzed in Figure 8. Besides, the ettringite peaks presented considerable increments in their intensities for all ages, while that the calcite peaks decreased at 28 days of hydration, due to the synergy between the materials, to probably form the CS and CO products.

Regarding the amount of water present in the hydration process, it was observed that cementitious pastes with a water/binder ratio of 0.3 presented a lower intensity in the portlandite peaks and presence of amorphous halo since the initial ages, while at 28 days of hydration, the portlandite peaks suffered a reduction and the amorphous halo an increase, indicating a high pozzolanicity and formation of C-S-H for the metakaolin used in the study. Already the cementitious pastes with a w/b ratio of 0.4 did not present a very different behavior when compared to pastes with a w/b ratio of 0.3 , only a lesser presence of amorphous halo for the early ages. When analyzing the cementitious pastes with a w/b ratio of 0.5 , it can be observed that in the early ages already existed the predominance of portlandite peaks, and with just 3 days it was already possible to identify the consumption of these crystals, beyond the increase of the amorphous halo and ettringite peaks, indicating the action of the pozzolanic reaction. Besides, the cementitious pastes with a greater amount of water presented, throughout the hydration process, peaks with higher intensities for CS and CO products, mainly for the age of 28 days, confirming that the increase of the $\mathrm{w} / \mathrm{b}$ ratio favors the growth not only from portlandite crystals but also the formation of the CS and CO peaks, for pastes containing metakaolin.

The results found are consistent with the results of some researchers who presented a similar behavior in the hydration process for the mineralogical phases identified in this study, mainly for the portlandite peaks (P), which in the cementitious pastes containing metakaolin and silica fume, decreased at 28 days due to the progress of hydration of the alite and belite phases and of the pozzolanic reactions [9]-[11], [14], [19].

It was still observed the importance of water in the hydration reactions, because when increasing the water/binder ratio in all cementitious pastes, it was noted a growth in the intensity of the portlandite peaks, a reduction in the intensity of the alite and belite phases, and the presence of more intense amorphous halo, mainly for the water/binder ratio of 0.5 in the age of 28 days. The $\mathrm{w} / \mathrm{b}$ ratio of 0.5 presented better hydration due to having a larger amount of water, generating greater efficiency in the hydration process, and with this, more reinforced hydration products. However, the disadvantage of this higher $\mathrm{w} / \mathrm{b}$ ratio was in the increase generated in the ettringite peaks for all pastes.

\subsection{Evaluation of the influence of supplementary cementitious materials (SCMs)}

Figure 9 is presented the diffractograms of the cementitious pastes with 28 days of hydration, in which was used three different water/binder ratios and two supplementary cementitious materials (SCMs) with 10 and $20 \%$ of mass substitution on Portland cement, that were the silica fume and metakaolin, respectively. It is important to note that to make the comparative analysis, the cementitious pastes presented in Figure 9, were prepared with different contents of Portland cement due to the percentage of substitution performed being different for the silica fume and metakaolin. Also, it was opted to work with mass substitutions due to the use of SCMs in the study, in which by adding SCMs through the replacement of cement, it can be avoided practical problems with water demand, hydration heat, retraction, and others in the cementitious matrix, mainly for Portland cement pastes with low water/binder ratio. 


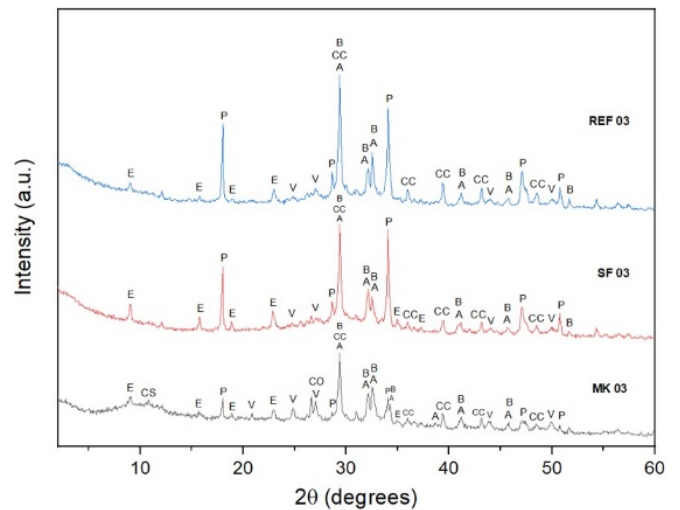

(A)

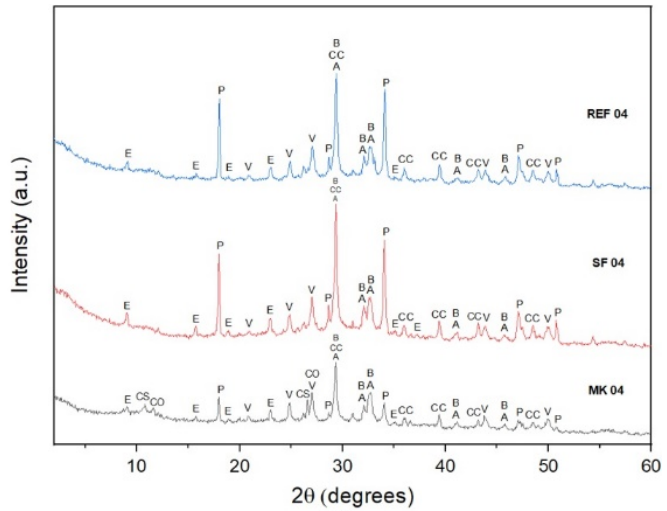

(B)

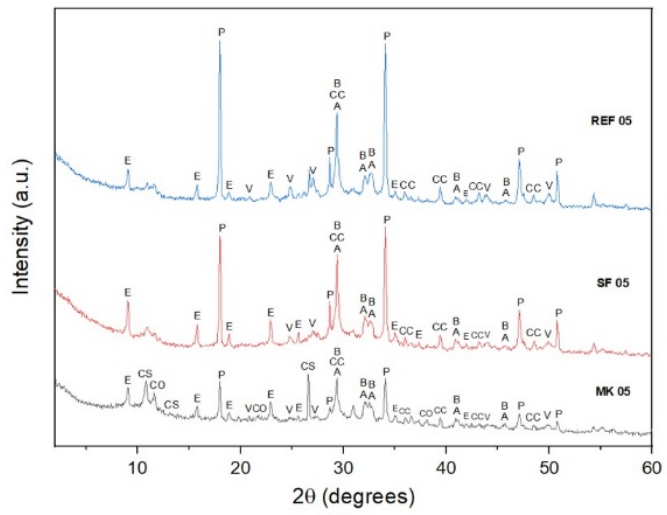

(C)

Figure 9. Diffractograms of the cement pastes without supplementary cementitious materials (REF), with the replacement of Portland cement by $10 \%$ of silica fume (SF) and with the replacement of Portland cement by $20 \%$ of metakaolin (MK), with 28 days of hydration for water/binder ratio of 0.3 (A), 0.4 (B), and 0.5 (C). E- Ettringite, P-portlandite, V-vaterite, A-alite, CC-calcite, B-belite, CS-hydrated calcium aluminum silicate, CO-hydrated calcium aluminum oxide.

Regarding the reference cementitious pastes (REF), through the qualitative analysis for the pastes containing silica fume (SF 03, SF 04, and SF 05), it is possible to observe that the replacement of Portland cement by $10 \%$ of this mineral addition generated a decrease in the intensity of the peaks of the mineralogical phases identified in the diffractograms, highlighting mainly the peaks referring to portlandite $(\mathrm{P})$. This behavior was due to the replacement of cement and pozzolanic reactions, in which the $\mathrm{SiO}_{2}$ particles, present in the silica fume, react chemically with the calcium hydroxide, formed by the cement hydration, to form secondary hydrated calcium silicate (C-S-H), behavior also observed in the studies of [10], [39]-[41]. This increment of C-S-H can be viewed through the amorphous halos formed for the cementitious pastes containing silica fume, which have greater intensities when compared with the amorphous halos present in the reference pastes.

It can still be observed that the intensities of the peaks referring to the alite (A) and belite (B) phases decreased, while that for the ettringite peaks was noticed a growth in all pastes containing silica fume concerning reference pastes, indicating the acceleration of the hydration and cement substitution. All these results are connected to the effects obtained by the utilization of the silica fume together with the Portland cement, which due to its properties of highly reactive materials occurs a pozzolanic reaction that generates an increase in the degree of cement hydration. The silica fume particles can act as nucleation points that also cause an acceleration in cement hydration [11], [42], [43]. These results presented for the pastes containing silica fume were also observed in other studies, which evidenced the same qualitatively phenomenon, in which the pozzolanic reaction of this material could clearly reduce the calcium hydroxide content [10], [11], [14], [19], [23], [44].

In the diffractograms of the pastes containing metakaolin (MK 03, MK 04, and MK 05), through the qualitative analysis, it was observed when comparing with reference cementitious pastes (REF) that, when replacing $20 \%$ of Portland cement by metakaolin, it was also occurred a decrease in the intensity of the calcium hydroxide (P) crystals, being of form more effective than the observed for the replacement of $10 \%$ of Portland cement by silica fume. This behavior is due to 
not only the different percentages for the cement contents but also due to the pozzolanic reactions because the metakaolin is a highly reactive and finely ground pozzolan, rich in $\mathrm{SiO}_{2}$ and $\mathrm{Al}_{2} \mathrm{O}_{3}$ in its chemical composition. Thus, beyond the silica particles, the alumina contained in the metakaolin when getting in contact with portlandite reacts and forms secondary C-S-H together with aluminate phases, constituting the pozzolanic reactions, and thereby generating the decrease of the mineralogical phases of portlandite, observed in these pastes. This behavior was also observed in other studies through the phases identified, in which the use of metakaolin provided a higher consumption of portlandite, which resulted in less intensity of peak portlandite [4], [5], [8], [11], [13], [14], [19], [44], [45]. The presence of the amorphous structures of C-S-H can be confirmed through the amorphous halos, observed in the analyzes performed for Figure 9, in which it was clearly identified this behavior due to the pozzolanic reactions present. When compared with the other pastes in Figure 9, it was observed that the amorphous halos of pastes containing metakaolin are the most intense for all water/binder ratios, thus demonstrating a greater presence of amorphous structures.

As expected, it was also presented for the peaks referring to the silicate phases (alite and belite) a decrease of the intensity in relation to both reference pastes and pastes containing silica. Already for the ettringite products, it can be observed that for pastes containing metakaolin occurred an increase concerning reference pastes, a behavior also viewed for pastes containing silica fume, but to a lower proportion. Through these results, it is noted that the samples with metakaolin presented a higher degree of hydration in the cementitious pastes. This behavior for metakaolin can be justified through its pozzolanic properties, in which the effects of nucleation can act with more intensity in the case of the hydration products of the aluminate phase, thereby increasing the evolution of the hydration for pastes containing this material [4], [8], [11], [13], [43].

In general, the replacement of Portland cement by different supplementary cementitious materials (SCMs) presented results in the X-ray diffractograms that evidenced the performance of the pozzolanic reactions generated by these materials during the hydration process, causing the consumption or formation of certain mineralogical phases identified in the study. Also, when comparing the behavior of the influence of silica fume and metakaolin, it can be concluded that the replacement of Portland cement by silica fume caused a slight impact on its reactions, but the impact caused by metakaolin is more intense in the cementitious pastes, indicating a greater pozzolanic performance and increase of the hydration effects due to the high presence of alumina and fineness in its properties [8], [14], [46]. In other words, the metakaolin showed a high pozzolanicity due to be a pozzolanic material and highly reactive, presenting physical characteristics, as extremely fine particles and the high specific area, besides the chemical characteristics, which generate a pozzolanic reaction from the interaction between silica and alumina, present in the metakaolin. It is also important to highlight that these results are associated with the difference of the cement contents between the cementitious pastes containing SCMs and to the results of chemical and physical characterization presented by the silica fume, which is a densified silica fume, with a larger diameter of the particles when compared with the metakaolin, according to the results of laser granulometry.

\section{CONCLUSIONS}

Cementitious pastes with different water/binder ratios and with the replacement of Portland cement by $10 \%$ of silica fume and $20 \%$ of metakaolin were produced to evaluate the hydration process, through the microstructural analysis, using the X-ray diffraction test, in the ages of $1,3,7$, and 28 days of hydration. Based on the results obtained from the experimental program conducted, it can be concluded that:

- All the cementitious pastes presented similar mineralogical phases, except for pastes containing metakaolin, which during the hydration process presented the formation of aluminate phases, due to the presence of alumina in this material, denominated in this study as hydrated calcium aluminum silicate (CS) and hydrated calcium aluminum oxide (CO). These new products were formed from the metakaolin pozzolanic reaction, mainly at 28 days of hydration, where was it identified an increase in the intensity of the CS and CO peaks.

- From the variation of the water/binder ratio, it is possible to observe the importance of water in the hydration reactions, in which through the qualitative analysis, it was noted that by increasing the water/ binder ratio, the pastes obtained an increment in the portlandite and ettringite peaks, and consequently a higher consumption in the alite and belite phases, mainly for the water/binder ratio of 0.5 , which presented in all pastes these behaviors in a more intense way. Already for very low values of water/binder, there are less intense peaks of portlandite due to not having the presence of water enough in the cementitious matrix to occur total hydration.

- The metakaolin influenced the cementitious pastes of form more expressive than silica fume, as it is a pozzolanic material rich in silica and alumina, which when entering in contact with portlandite reacted and formed secondary C-S-H together with new aluminate phases, constituting the pozzolanic reactions. The presence of metakaolin indicated a greater pozzolanic performance and increase of the hydration effects, a 
behavior proven through the intensities of the mineralogical phases and of the formation of amorphous halos, which for cementitious pastes containing metakaolin presented of form more intense.

In general, when increasing the water/binder ratio, the pozzolanic and hydration reactions continued to occur, being that in a greater proportion, especially the metakaolin with greater reactivity.

\section{ACKNOWLEDGEMENTS}

The authors wish to thank the Universidade de Brasília (UnB/Brazil) and the financial support provided by the Conselho Nacional de Desenvolvimento Científico e Tecnológico (CNPq/Brazil), the Coordenação de Aperfeiçoamento de Pessoal de Nível Superior (CAPES/Brazil), and the Fundação de Apoio à Pesquisa do Distrito Federal (FAPDF/Brazil-Process: 0193.001700/2017).

\section{REFERENCES}

[1] F. Pelisser, P. J. P. Gleize, and M. D. Michel, "Propriedades nanomecânicas de pastas de cimento," Rev. IBRACON Estrut. Mater., vol. 4, no. 4, pp. 561-574, 2011, http://dx.doi.org/10.1590/S1983-41952011000400003.

[2] J. E. Rossen, B. Lothenbach, and K. L. Scrivener, "Composition of C-S-H in pastes with increasing levels of silica fume addition," Cement Concr. Res., vol. 75, pp. 14-22, 2015, http://dx.doi.org/10.1016/j.cemconres.2015.04.016.

[3] C. P. Figueiredo, F. B. Santos, O. Cascudo, H. Carasek, P. Cachim, and A. Velosa, "The role of metakaolin in the protection of concrete against the deleterious action of chlorides $\mathrm{O}$ papel do metacaulim na proteção dos concretos contra a ação deletéria de cloretos," Rev. IBRACON Estrut. Mater., vol. 7, no. 4, pp. 685-708, 2014, http://dx.doi.org/10.1590/S1983-41952014000400008.

[4] L. Krajči, I. Janotka, F. Puertas, M. Palacios, and M. Kuliffayová, "LONG: term properties of cement composites with various metakaolinite content," Ceram. Silik., vol. 57, no. 1, pp. 74-81, 2013.

[5] G. Puerta-Falla, M. Balonis, G. Le Saout, N. Neithalath, and G. Sant, "The influence of Metakaolin on limestone reactivity in cementitious materials," in Calcined Clays for Sustainable Concrete, K. Scrivener and A. Favier, Eds., Dordrecht: Springer, 2015, pp. 11-19. http://dx.doi.org/10.1007/978-94-017-9939-3_2.

[6] M. Antoni, J. Rossen, F. Martirena, and K. Scrivener, "Cement substitution by a combination of metakaolin and limestone," Cement Concr. Res., vol. 42, no. 12, pp. 1579-1589, 2012, http://dx.doi.org/10.1016/j.cemconres.2012.09.006.

[7] S. Tongbo, W. Bin, Z. Lijun, and C. Zhifeng, "Meta-Kaolin for high performance concrete," in Calcined Clays for Sustainable Concrete, K. Scrivener and A. Favier, Eds., Dordrecht: Springer, 2015, pp. 467-477. http://dx.doi.org/10.1007/978-94-017-99393 _58.

[8] P. Mikhailenko, F. Cassagnabère, A. Emam, and M. Lachemi, "Influence of physico-chemical characteristics on the carbonation of cement paste at high replacement rates of metakaolin," Constr. Build. Mater., vol. 158, pp. 164-172, 2018, http://dx.doi.org/10.1016/j.conbuildmat.2017.10.021.

[9] D. da Silva Andrade, J. H. da Silva Rêgo, P. Cesar Morais, and M. Frías Rojas, "Chemical and mechanical characterization of ternary cement pastes containing metakaolin and nanosilica," Constr. Build. Mater., vol. 159, pp. 18-26, 2018, http://dx.doi.org/10.1016/j.conbuildmat.2017.10.123.

[10] Z. Zhang, B. Zhang, and P. Yan, "Comparative study of effect of raw and densified silica fume in the paste, mortar and concrete," Constr. Build. Mater., vol. 105, pp. 82-93, 2016, http://dx.doi.org/10.1016/j.conbuildmat.2015.12.045.

[11] J. H. S. Rêgo, M. F. Rojas, A. M. Terrades, L. Fernández-Carrasco, E. R. Morales, and M. I. S. Rojas, "Effect of partial substitution of highly reactive mineral additions by Nanosilica in cement pastes," J. Mater. Civ. Eng., vol. 31, no. 1, pp. 1-11, 2019, http://dx.doi.org/10.1061/(ASCE)MT.1943-5533.0002567.

[12] H. M. Khater, "Influence of metakaolin on resistivity of cement mortar to Magnesium chloride solution," J. Mater. Civ. Eng., vol. 23, no. 9, pp. 1295-1301, 2011, http://dx.doi.org/10.1061/(ASCE)MT.1943-5533.0000294.

[13] S. Barbhuiya, P. L. Chow, and S. Memon, "Microstructure, hydration and nanomechanical properties of concrete containing metakaolin," Constr. Build. Mater., vol. 95, pp. 696-702, 2015, http://dx.doi.org/10.1016/j.conbuildmat.2015.07.101.

[14] P. Ghoddousi and L. Adelzade Saadabadi, "Study on hydration products by electrical resistivity for self-compacting concrete with silica fume and metakaolin," Constr. Build. Mater., vol. 154, pp. 219-228, 2017, http://dx.doi.org/10.1016/j.conbuildmat.2017.07.178.

[15] H. F. Campos, T. M. S. Rocha, G. C. Reus, N. S. Klein, and J. Marques Fo., "Determination of the optimal replacement content of Portland cement by stone powder using particle packing methods and analysis of the influence of the excess water on the consistency of pastes," Rev. IBRACON Estrut. Mater., vol. 12, no. 2, pp. 210-232, 2019, http://dx.doi.org/10.1590/s1983-41952019000200002.

[16] D. Alonso-Domínguez, I. Álvarez-Serrano, E. Reyes, and A. Moragues, "New mortars fabricated by electrostatic dry deposition of nano and microsilica additions: Enhanced properties," Constr. Build. Mater., vol. 135, pp. 186-193, 2017,

http://dx.doi.org/10.1016/j.conbuildmat.2017.01.011. 
[17] I. P. Sfikas, E. G. Badogiannis, and K. G. Trezos, "Rheology and mechanical characteristics of self-compacting concrete mixtures containing metakaolin," Constr. Build. Mater., vol. 64, pp. 121-129, 2014, http://dx.doi.org/10.1016/j.conbuildmat.2014.04.048.

[18] L. Feng, P. Zhao, Z. Wang, J. Gao, X. Su, and H. Li, "Improvement of mechanical properties and chloride ion penetration resistance of cement pastes with the addition of pre-dispersed silica fume," Constr. Build. Mater., vol. 182, pp. 483-492, 2018, http://dx.doi.org/10.1016/j.conbuildmat.2018.06.053.

[19] G. Ling et al., "Rheological behavior and microstructure characteristics of SCC incorporating metakaolin and silica fume," Materials, vol. 11, no. 12, pp. 2576, 2018, http://dx.doi.org/10.3390/ma11122576.

[20] J. Hoppe Fo., A. Gobbi, E. Pereira, R. S. Tanaka, and M. H. F. De Medeiros, "Atividade pozolânica de adições minerais para cimento portland (Parte ii): índice de atividade pozolânica com cimento portland (IAP), difração de raios-x (DRX) e termogravimetria (TG/DTG)," Rev. Mat., vol. 22, no. 3, 2017, http://dx.doi.org/10.1590/S1517-707620170003.0207.

[21] Z. Zhang, B. Zhang, and P. Yan, "Hydration and microstructures of concrete containing raw or densified silica fume at different curing temperatures," Constr. Build. Mater., vol. 121, pp. 483-490, 2016, http://dx.doi.org/10.1016/j.conbuildmat.2016.06.014.

[22] R. C. O. Romano, M. A. Cincotto, and R. G. Pileggi, "Hardening phenomenon of Portland cement suspensions monitored by Vicat test, isothermal calorimetry and oscillatory rheometry," Rev. IBRACON Estrut. Mater., vol. 11, no. 5, pp. 949-959, 2018, http://dx.doi.org/10.1590/s1983-41952018000500003.

[23] D. C. S. Garcia, M. M. N. S. Soares, A. C. S. Bezerra, M. T. P. Aguilar, and R. B. Figueiredo, "Microstructure and hardness of cement pastes with mineral admixture," Rev. Mat., vol. 22, no. 2, 2017, http://dx.doi.org/10.1590/S1517-707620170002.0145.

[24] Associação Brasileira de Normas Técnicas, Cimento Portland - Requisitos, NBR 16697, 2018.

[25] Associação Brasileira de Normas Técnicas, Cimento Portland - Análise Química - Determinação de Perda ao Fogo, NM 18, 2012.

[26] Associação Brasileira de Normas Técnicas, Cimento Portland - Determinação dos Tempos de Pegas, NBR 16607, 2018.

[27] Associação Brasileira de Normas Técnicas, Cimento Portland - Determinação da Pasta de Consistência Normal, NBR $16606,2017$.

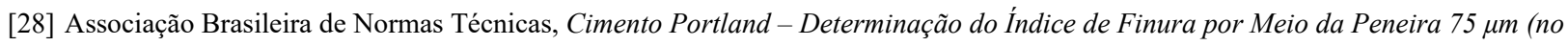
200), NBR 11579, 2013.

[29] Associação Brasileira de Normas Técnicas, “Cimento Portland e Outros Materiais em Pó - Determinação da Massa Específica, NBR 16605, 2017.

[30] Associação Brasileira de Normas Técnicas, Cimento Portland - Determinação da Resistência à Compressão de Corpos de Prova Cilindricos, NBR 7215, 2019.

[31] B. S. Santos, D. D. M. Albuquerque, and D. V. Ribeiro, "Efeito da adição do metacaulim na carbonatação de concretos de cimento Portland," Rev. IBRACON Estrut. Mater., vol. 13, no. 1, pp. 10-18, 2020, http://dx.doi.org/10.1590/S1983-41952020000100002.

[32] Associação Brasileira de Normas Técnicas, Agregados - Determinação da Massa Unitária e do Volume de Vazios, NM 45, 2006.

[33] Associação Brasileira de Normas Técnicas, Sílica Ativa para Uso com Cimento Portland em Concreto, Argamassa e Pasta - Parte 4: Determinação da Finura por Meio da Peneira 45 um, NBR 13956-4, 2012.

[34] American Society for Testing and Materials, Standard Test Method for Specific Surface Area of Alumina or Quartz by Nitrogen Adsorption, C1069, 2014.

[35] Associação Brasileira de Normas Técnicas, Sílica Ativa para Uso com Cimento Portland em Concreto, Argamassa e Pasta - Parte 1: Requisitos, NBR 13956-1, 2012.

[36] Associação Brasileira de Normas Técnicas, Água para Amassamento do Concreto. Parte 1: Requisitos, NBR 15900-1, 2009.

[37] B. Scrivener, K. Snellings, and R. Lothenbach, A Practical Guide to Microstructural Analysis of Cementitious Materials. Boca Raton: CRC Press, 2016.

[38] A. M. Neville and J. J. Brooks, Tecnologia do Concreto, 2a ed. Porto Alegre: Bookman, 2013.

[39] A. Hermann, E. A. Langaro, S. H. L. Silva, and N. S. Klein, "Empacotamento de partículas de cimento e sílica ativa em pastas pelo uso de modelo analítico," Rev. IBRACON Estrut. Mater., vol. 9, no. 1, pp. 48-65, 2016, http://dx.doi.org/10.1590/S198341952016000100004.

[40] V. M. Silva, “Ação da carbonatação em vigas de concreto armado em serviço, construídas em escala natural e reduzida,” Ph.D. dissertation, Univ. São Paulo, São Carlos, 2007.

[41] V. M. S. Capuzzo, C. M. C. Gurjão, and J. B. L. Liborio, "Influência da carbonatação e das adições minerais na porosidade do concreto," in I Enc. Luso-Bras. Degrad. Estrut. Concr. Arm., Salvador, 2014.

[42] D. Y. Lei, L. P. Guo, W. Sun, J. Liu, X. Shu, and X. L. Guo, "A new dispersing method on silica fume and its influence on the performance of cement-based materials," Constr. Build. Mater., vol. 115, pp. 716-726, 2016, http://dx.doi.org/10.1016/j.conbuildmat.2016.04.023.

[43] B. Lothenbach, K. Scrivener, and R. D. Hooton, "Supplementary cementitious materials," Cement Concr. Res., vol. 41, no. 12, pp. 1244-1256, 2011, http://dx.doi.org/10.1016/j.cemconres.2010.12.001. 
[44] M. H. F. Medeiros, J. W. Raisdorfer, and J. Hoppe Fo., "Influência da sílica ativa e do metacaulim na velocidade de carbonatação do concreto: relação com resistência, absorção e relação a/c," Ambient. Constr., vol. 17, no. 4, pp. 125-139, 2017, http://dx.doi.org/10.1590/s1678-86212017000400189.

[45] D. Zhao and R. Khoshnazar, "Microstructure of cement paste incorporating high volume of low-grade metakaolin," Cement Concr. Compos., vol. 106, pp. 103453, 2020, http://dx.doi.org/10.1016/j.cemconcomp.2019.103453.

[46] N. Shafiq, M. F. Nuruddin, S. U. Khan, and T. Ayub, "Calcined kaolin as cement replacing material and its use in high strength concrete," Constr. Build. Mater., vol. 81, pp. 313-323, 2015, http://dx.doi.org/10.1016/j.conbuildmat.2015.02.050.

Author contributions: MMLP and ALRS: conceptualization, methodology, writing, data curation; VMSC and RML: methodology, data curation, formal analysis.

Editors: Edna Possan, Guilherme Aris Parsekian. 